\title{
A TANÖSVÉNYEK SZEREPE A FENNTARTHATÓSÁGRA NEVELÉSBEN
}

\section{Kollarics Tímea}

Nyugat-magyarországi Egyetem Benedek Elek Pedagógiai Kar, Neveléstudományi és Pszichológiai Intézet, Szakmai Tanárképzési Tanszék

\section{Bevezetés}

A tanulmány a tanösvények fenntarthatóságra nevelésben betöltött szerepét vizsgálja, bemutatva annak a mikrokutatásnak az eredményeit, amelyet közel négyszáz fő önkéntes közremüködésével végeztünk kérdőíves módszerrel.

\section{EIméleti háttér}

Az utóbbi években a környezeti nevelés átalakulásával eljutottunk hazánkban is a fenntarthatóság pedagógiájának összetett fogalmáig. A fenntarthatóság a fenntartható fejlődés eszméjéből kiindulva magában foglalja a környezeti, társadalmi és gazdasági fenntarthatóságot, vagyis azt az ideális, harmonikus egyensúlyt tűzi ki célul, amikor a hármas egységben nem sérülnek egyik ,fél” érdekei sem. Az Egyesült Nemzetek Szervezete 2002-ben a 2005-2014 közötti időszakot a „Tanulás a fenntarthatóságért” évtizedének nyilvánította, amelynek következtében Magyarországon is számos jó kezdeményezés, stratégiai tervezés, szervezetitartalmi átalakulás indult el és valósult meg az intézményes és intézményen kívüli oktatás, nevelés terén. A fenntarthatóságot középpontba helyező pedagógiai munka célja az, hogy a nevelés hozzájáruljon a fenntartható, felelős társadalmi müködésmódok kialakításához, tehát nemcsak a környezeti szemléletformálást foglalja magában, hanem a környezeten túl az egymásért és saját magunkért érzett felelősségérzetet is hivatott erősíteni (Havas és Varga, 2006).

A tanösvény mint a terepi bemutatóhelyek egyik típusa, fontos szerepet tölthet be a fenntarthatóságra nevelésben minden korosztály esetében. A magyar „tanösvény” elnevezésnek angol nyelvterületen az interpretational trail, a nature trail és a nature experience trail kifejezések felelnek meg, német nyelvterületen leginkább a Lehrpfad, Erlebnispfad elnevezéseket alkalmazzák. Francia területeken a Sentier didactique kifejezéssel találkozhatunk (Kiss, 2007). A tanösvény fogalma külföldön több jelentéstartalommal bír, magában foglalja az interpretáció, az informálás és az élményszerzés együttes funkcióját. Az interpretáció szerepe kiemelt, az informáláson alapuló felfedezést tűzik ki célul, a látogatókat aktivizálják, bevonják a kommunikációs folyamatokba, lehetővé teszik számukra az önálló élményszerzést. Bemutatási formájukra általánosan jellemző, hogy érzelmeket váltanak ki a látogatókból (Petyerák-Varga, 2009). Hazánkban az első tanösvénynek tekinthető létesítményt 1972-ben létesítették a Szalajka-völgyben, amelyet kezdetben erdei tanulóútnak, sétaútnak neveztek 
(Kárász, 2003). Kiss Gábor megfogalmazása szerint „a tanösvény a környezetismereti bemutatóhelyek egyik típusa. Olyan tematikus útvonal, ahol az érintett terület természeti és kulturális (kultúrtörténeti) öröksége állomáshelyekhez kötödően, általában táblák és/vagy kiadványok segitségével kerül bemutatásra, igy a látogatók részéröl önálló, aktív ismeretszerzést tesz lehetövé” (Kiss, 2007. 12. o.).

\section{A kutatás célja és módszerei}

A tanösvényekkel kapcsolatos doktori kutatás célja nemzetközi kitekintéssel kiegészítve bemutatni a tanösvények szerepét a környezeti szemléletformálásban, feltárni a tervezés során a szakmai és pedagógiai-módszertani szempontok integrálásának általános szempontjait, valamint szemléltetni a fenntartható fejlődés dimenzióinak fontosságát a tanösvények tervezésénél és a gyakorlati alkalmazásuk során. A kutatás legfontosabb területe a hazai tanösvények hatékonyságvizsgálata.

A kutatás szerves részét képezte az a mikrokutatás, amely közel négyszáz válaszadó önkéntes közremüködésével készült kérdőíves módszerrel. A kérdőív online és papír alapon is terjesztésre került, biztosítva ezáltal a lakosság minél szélesebb körü elérésének lehetőségét. A vizsgálat elsődleges célja az volt, hogy átfogó képet kapjunk a magyar lakosság tanösvényekhez füződő viszonyáról és a tanösvényekkel szembeni elvárásokról. A felmérés 2011. és 2012. években zajlott, az anonimitás biztosításával. A felmérésben nyílt és zárt kérdéseket alkalmaztunk, egyenlő arányban. A kérdések között szerepeltek eldöntendő, zárt kérdések, fogalomtársítási, asszociációs jellegü kérdések, valamint skálaértékelés is. A nyílt kérdésekben elsősorban a látogatók fogalomalkotására, gondolataira, véleményére voltunk kíváncsiak. Az eredmények feldolgozása egyszerü összesítéssel, gyakoriság-, illetve átlagszámítással, valamint tartalomelemzéssel történt.

\section{Eredmények}

A kérdéssor első részében a kirándulási szokásokról kérdeztük a válaszadókat, amely szerint a válaszadók csaknem 41 százaléka (161 fö) hetente, 24 százaléka (96 fö) havonta, 12 százalék (49 fó) évente 2-3 alkalommal, és a válaszadók 23 százaléka (91 fö) alkalomszerüen kirándul. A megkérdezettek mindössze 3 százaléka (12 fö) kirándul szervezetten, vezetővel, 13 százalék (52 fö) csoportosan, a többség, 78 százalék (308 fö) egyénileg vagy családdal, és 6 százalékuk (25-en) egyéb módon, például barátokkal, kutyával, párral, munkahely által keresi fel a természetet.

A tanösvényekkel kapcsolatos kérdések egyik legfontosabb eleme volt annak a felmérése, hogy a válaszadók hallottak-e már a tanösvényekről. Az eredmény pozitív, a megkérdezettek közül 378-an, vagyis 95 százalékuk hallott már ezekről a létesítményekröl, és közülük 338-an jártak is már tanösvényen. Az 59 fö közül, akik nem jártak tanösvényen, 19-en nem is hallottak még róla, a többi 40 fö ugyan hallott már a tanösvényekröl, de eddig nem volt ideje, alkalma egy 
ilyen létesítmény felkeresésére, vagy információ- illetve motivációhiányra hivatkozott.

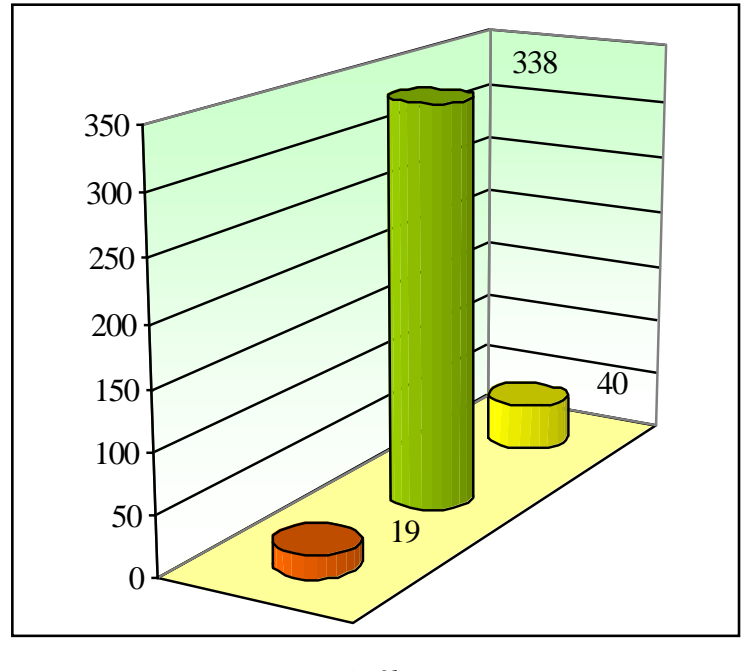

1. ábra

A tanösvények ismertsége $(N=397)$

A következő nyílt kérdésben arra szerettünk volna választ kapni, hogy a látogatók véleménye szerint mit nevezünk tanösvénynek. 341 főtől kaptunk értékelhető választ, a válaszok közül a legtöbben az „út” (181 alkalommal) kifejezést említették, ezt követte 92 alkalommal a „természet”, majd az „erdő, erdei” kifejezések 65 alkalommal. A „táblák” kulcsszó 60 alkalommal fordult elő. A „túra, túraútvonal” kifejezések 59 alkalommal kerültek megfogalmazásra, majd a fentieket követte gyakoriságban a „növény” kifejezés (51 alkalom), ezzel csaknem megegyező számban fordult elő a „bemutató” (50), 46-szor az „ösvény” szó. Az 1. táblázatban látható eredmények alapján a lakosság legnagyobb arányban a természetben található kitáblázott, kijelölt erdei túraútvonallal, ösvénnyel azonosítja a tanösvényeket, ahol állatok, növények bemutatása történik.

\begin{tabular}{|l|c|c|}
\hline $\begin{array}{c}\text { Kifejezés a } \\
\text { válaszadó } \\
\text { meghatározásában }\end{array}$ & $\begin{array}{c}\text { Kifejezés } \\
\text { elöfordulási } \\
\text { gyakorisága } \\
(\mathrm{N}=341)\end{array}$ & $\begin{array}{c}\text { Kifejezés } \\
\text { előfordulása az } \\
\text { összes válasz } \\
\text { arányában } \\
(\mathrm{N}=341)\end{array}$ \\
\hline Út & 181 & $53 \%$ \\
\hline Természet & 92 & $27 \%$ \\
\hline Erdö, erdei & 65 & $19 \%$ \\
\hline Táblák & 60 & $17,6 \%$ \\
\hline Túra, túraútvonal & 59 & $17,3 \%$ \\
\hline Növény & 51 & $15 \%$ \\
\hline Bemutató & 50 & $14,7 \%$ \\
\hline Ösvény & 46 & $13,5 \%$ \\
\hline Kijelölt & 42 & $12,3 \%$ \\
\hline Információ & 36 & $10,5 \%$ \\
\hline
\end{tabular}




\begin{tabular}{|l|c|c|}
\hline Oktatás, oktató & 36 & $10,5 \%$ \\
\hline Állat, állatok & 31 & $9 \%$ \\
\hline Táj & 28 & $8,2 \%$ \\
\hline Élővilág & 26 & $7,6 \%$ \\
\hline Érték & 25 & $7,3 \%$ \\
\hline Séta & 18 & $5,2 \%$ \\
\hline Fa, fák & 15 & $4,4 \%$ \\
\hline
\end{tabular}

A tanösvény fogalmának meghatározása a látogatók szerint

A következő fogalomtársítási, asszociációs jellegü kérdésben arra vártuk a választ, hogy a látogatóknak mely három dolog jut először eszébe a tanösvényekről. A természet $(9,8 \%)$, az erdő $(6,8 \%)$, a növények $(5,7 \%)$ és a táblák $(4,1 \%)$ említése volt a leggyakoribb az előző válasz eredményeihez hasonlóan, az állatok (4,8 \%) előkelő helyet foglaltak el, míg az út, túraút kifejezés a fogalomtársításnál lényegesen hátrébb szorult (2,5\%). Figyelemre méltó, hogy a tanösvényekről mindössze a látogatók 0,8 , illetve 0,5 százalékának jutott eszébe a természetvédelem és a környezetvédelem, valamint az ehhez kapcsolódó környezeti nevelés.

A felmérés kardinális pontját képezte az a kérdés, amelyben azt szerettük volna felmérni, hogy a látogatókat bizonyos látnivalók mennyire érdeklik egy tanösvény bejárásakor. Tizenegy lehetőséget adtunk meg, ezeket a látnivalókat érdeklődési körük alapján, ötfokozatú skálán kellett osztályozniuk a válaszadóknak, ahol az egyes azt jelentette, hogy egyáltalán nem érdekli, az ötös pedig azt, hogy nagyon érdekli az adott objektum. Az előző kérdések válaszaiból kiindulva a látogatók a tapasztalataik alapján elsősorban a növények bemutatásával azonosítják a tanösvényeket, de az állatok bemutatására lennének kíváncsiak elsődlegesen, és csak másodsorban érdeklik őket a növények. A harmadik legmagasabb átlagot a helyi sajátosságok kapták a válaszadóktól, és négyes feletti átlagot mutatnak a vizek is. A fenntartható megoldások, a jövő kérdései az érdeklődési skálán kevéssel négy alatt maradtak. 


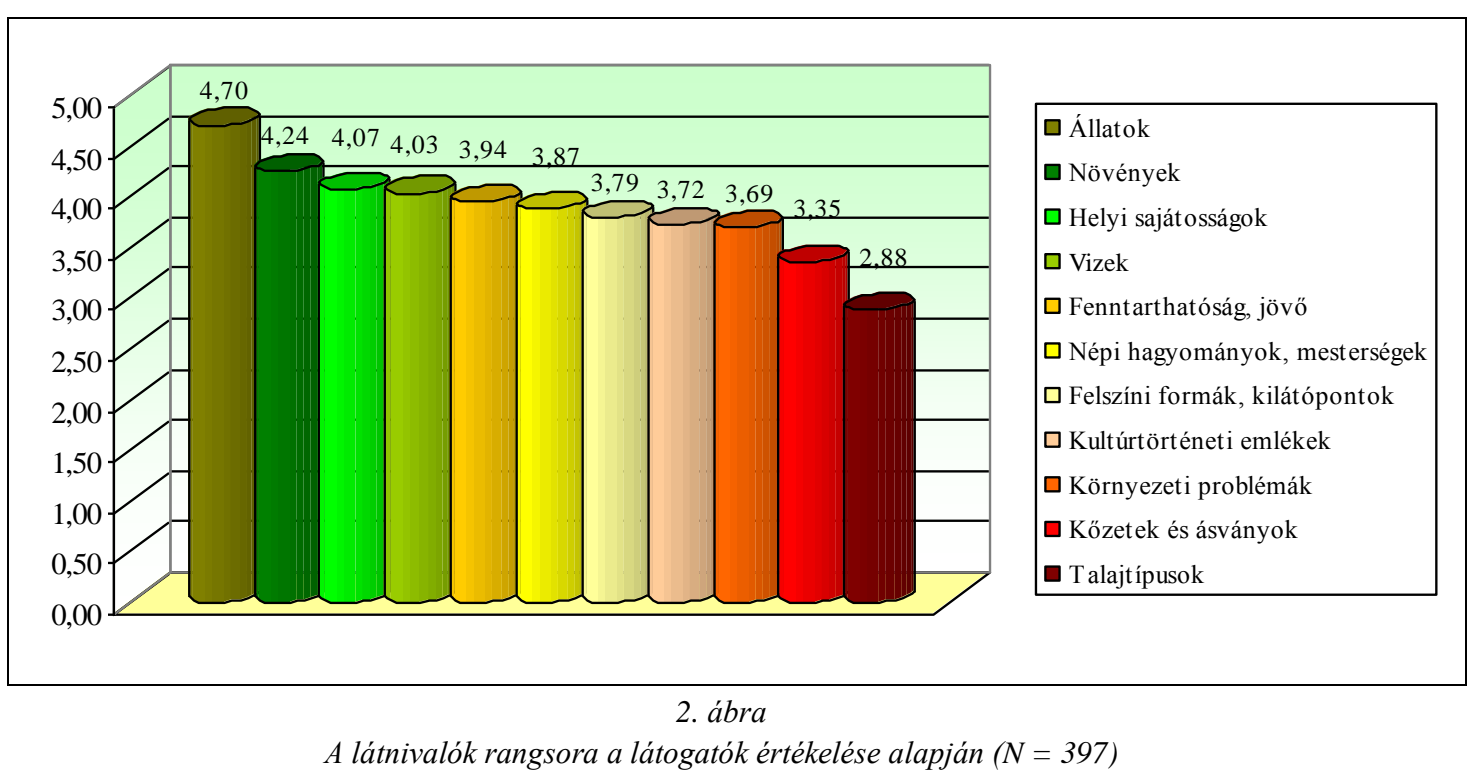

A következő nyílt kérdésben arra kértük a válaszadókat, hogy nevezzék meg a jó tanösvény jellemzőit három szóban. A 914 értékelhető válaszból legtöbbször az alábbi jelzők fordultak elő: érdekes (61), könnyen járható (49) és tiszta (48). Fontos tulajdonság még az informativitás, az érthetőség és a látványosság is. A jó tanösvény továbbá természetközeli, karbantartott, átlátható, figyelemfelkeltő és rövid.

Az utolsó elötti kérdésből azt szerettük volna megtudni, hogy a válaszadók véleménye szerint milyen hasznos funkciói vannak egy tanösvénynek. Az eredmények a 2. táblázatban láthatók. A kapott eredmények alapján elmondható, hogy a válaszadók a természet megismerését és megszerettetését tartották a tanösvények elsődleges funkciójának. Jelentős szerepe van még a tanösvényeknek az ismeretterjesztés és az oktatás terén, valamint a kikapcsolódás szempontjából is hasznos egy ilyen létesítmény. Figyelemre méltó tehát, hogy a látogatók nemcsak a tanösvények oktató-nevelő funkcióját emelték ki a válaszokban, hanem a szabadidő eltöltése, a kikapcsolódás is jelentős szerepet kapott.

Az utolsó, nyílt kérdésben a válaszadóknak lehetőségük volt jellemezni a számukra ideális tanösvényt. 287 látogatótól hasznos, értékes véleményeket kaptunk. A válaszadók 54 alkalommal említették az állatvilág megismerésének lehetőségét, 46 alkalommal a növények bemutatását, 22 fö emelte ki az erdő megismerését. A válaszok nagyon hasonlítanak az előző kérdések eredményeihez, a leggyakoribb jellemzések közé tartozott a jól járható, nem túl hosszú útvonal, a változatos, figyelemfelkeltő kivitelezés, a természetközeliség és a pihenöhelyekkel való ellátottság. A válaszadók öt százalékának az interaktivitás is fontos egy tanösvényen, négy százalékuk pedig játékos elemeket is szívesen lát. Az utolsó kérdés eredményei alapján elmondható, hogy a látogatók a természeti értékek (mindenekelőtt növények és állatok) megismerése mellett a szabadidő kellemes eltöltésének lehetőségét várják el a tanösvényektől, ahol gyerekekkel, 
családi programként, játékosan, pihenőhelyekkel, berendezési tárgyakkal tarkítva ismerkedhetnek meg a természeti látványosságokkal.

\begin{tabular}{|l|c|c|}
\hline \multicolumn{1}{|c|}{$\begin{array}{c}\text { Hasznossági funkció } \\
\text { megnevezése }\end{array}$} & $\begin{array}{c}\text { Összes } \\
\text { elöfordulás } \\
(\mathrm{N}=794)\end{array}$ & $\begin{array}{c}\text { Elöfordulás az összes } \\
\text { válasz arányában } \\
(\mathrm{N}=794)\end{array}$ \\
\hline $\begin{array}{l}\text { Természet megismerése és } \\
\text { megszerettetése }\end{array}$ & 95 & $12 \%$ \\
\hline Ismeretterjesztés & 77 & $9,7 \%$ \\
\hline Oktatás & 54 & $6,8 \%$ \\
\hline Kikapcsolódás & 39 & $4,9 \%$ \\
\hline Tanulás & 31 & $3,9 \%$ \\
\hline Bemutatás & 30 & $3,8 \%$ \\
\hline Tanítás & 28 & $3,5 \%$ \\
\hline Élővilág megismerése & 18 & $2,3 \%$ \\
\hline Nevelés & 17 & $2,1 \%$ \\
\hline $\begin{array}{l}\text { Környezeti nevelés, } \\
\text { környezettudatosság }\end{array}$ & 17 & $2,1 \%$ \\
\hline Tájékoztatás & 14 & $1,8 \%$ \\
\hline Informálás & 14 & $1,8 \%$ \\
\hline Természetvédelem & 14 & $1,8 \%$ \\
\hline Szemléletformálás & 13 & $1,6 \%$ \\
\hline Állatok megismerése & 13 & $1,6 \%$ \\
\hline Értékek megismerése & 12 & $1,5 \%$ \\
\hline Környezet megismerése & 9 & $0,9 \%$ \\
\hline Kirándulás & 7 & \\
\hline $\begin{array}{l}\text { Városi emberek } \\
\text { természetszeretetre nevelése }\end{array}$ & 6 táblázat: & \\
\hline Élményszerzés & & \\
\hline & & \\
\hline A tanóny hasznossága & \\
\hline
\end{tabular}

\section{Összegzés és következtetések}

A tanösvény fogalma, a tanösvények típusai szerteágazóak Magyarországon, mint ahogy a róluk kialakult kép is sokszínü a lakosság körében. A tanösvények szemléletformáló hatásáról, ismeretszerzési hatékonyságáról és az eredményes tervezési módszerekről szóló kutatás szerves részét képezte az a kérdőíves mikrokutatás, amelynek elsődleges célja az volt, hogy átfogó képet kapjunk a magyar lakosság tanösvényekhez füződő viszonyáról, a látogatókat leginkább érdeklő témákról és a tanösvényekkel szembeni elvárásokról.

A válaszadók 95 százaléka hallott már a tanösvényekről, 85 százalékuk járt is már ilyen helyen, így az eredmények alapján azt a következtetést vonhatjuk le, hogy a magyarok többsége ismeri a tanösvényeket. A természetjárókban a válaszok alapján a klasszikus tanösvény képe él: a lakosság legnagyobb arányban a természetben található kitáblázott, kijelölt erdei túraútvonallal, ösvénnyel azonosítja a tanösvényeket, ahol állatok, növények bemutatása történik. Az eredmények alapján a látogatókat leginkább érdeklő látnivalók az állatok, a 
növények és a helyi jellegzetességek, legkevésbé a kőzetek és a talajok állnak az érdeklődés középpontjában a válaszadók rangsora alapján. A látogatók többségének véleménye szerint egy jó tanösvény érdekes, könnyen járható, tiszta, emellett informatív, érthető, látványos, természetközeli, karbantartott, átlátható, figyelemfelkeltő és nem túl hosszú. A tanösvények legföbb funkciója a látogatók szerint elsősorban a természet megismerése és megszerettetése. Jelentős szerepe van még a tanösvényeknek az ismeretterjesztés, oktatás terén és a kikapcsolódás szempontjából is hasznos egy ilyen létesítmény. Az ideális tanösvénytöl a látogatók a természeti értékek (elsősorban növények és állatok) megismerése mellett a szabadidő kellemes eltöltésének lehetőségét várják el, ahol gyerekekkel, családi programként, játékosan, pihenőhelyekkel, berendezési tárgyakkal tarkítva ismerkedhetnek meg a természeti látványosságokkal.

A mikrokutatás eredményeit a fenntarthatósági dimenziók (Stoltenberg, 2005) tükrében vizsgálva érdekes összefüggéseket találunk, amelyek azt bizonyítják, hogy a fenntarthatóságra nevelésben jelentős szerep jut a tanösvények szemléletformáló hatásának. Az ökológiai aspektus a tanösvények esetében nagyon hangsúlyos, hiszen a legtöbb tanösvény természetismereti tartalmú, amely a látogatók fogalomtársításaiban, elvárásaiban is megfigyelhető volt (preferált látnivalók, természetközeliség, erdei útvonal). A válaszadók az esztétikai szempontokat is fontosnak tartották, a harmonikus, rendezett létesítmények iránti igényüket meg is fogalmazták. A tanösvények jóléti funkcióval is rendelkeznek, a kérdöíves felmérés válaszaiban több kérdés során is megjelent a kikapcsolódás és az élményszerzés, mint elvárt hasznossági funkció. A tanösvények kulturális értékek bemutatására is hivatottak, ezt bizonyítja a látogatók rangsora, ahol a helyi jellegzetességek a harmadik helyre kerültek az érdeklődés skáláján. Ami a fenntarthatóság ökonómiai dimenzióját illeti, a tanösvények gazdasági hasznosulását is érdemes lenne vizsgálni, amelyhez alapot jelentenének a külföldi országok ökoturisztikai központjainak, látnivalóinak látogatottsági eredményei. Amennyiben összesítjük a tanösvények jellemzőit a fenntarthatósági funkciók mentén, elmondhatjuk, hogy a látogatók szemléletformálása úgy történik meg a bejárás során, hogy közben élményszerü, tapasztalat-alapú felfedezés és ismeretszerzés történik, vagyis a tanösvények indirekt nevelést valósítanak meg, ez pedig összhangban áll a fenntarthatóság pedagógiai céljaival.

\section{Irodalom}

Havas Péter és Varga Attila (2006): A környezeti neveléstől a fenntarthatóság pedagógiai gyakorlata felé. In: Varga Attila (szerk.) Tanulás a fenntarthatóságért. Országos Közoktatási Intézet, Budapest. 49-72.

Kárász Imre (2003, szerk.): Természetismereti tanösvények Észak-Magyarországon. Tủzliliom Környezetvédelmi Oktatóközpont Egyesület, Eger. 
Kiss Gábor (2007, szerk.): Tanösvények tervezése: módszertani útmutató. Bükki Nemzeti Park Igazgatóság, Eger.

Petyerák Viktor (2009): Virtuális tanösvény készitésének alternatívái a Csörsz-Arok példáján. [Szakdolgozat]. Szent István Egyetem Mezőgazdaság- és Környezettudományi Kar, Gödöllö.

Stoltenberg, Ute (2005): Bildung für nachhaltige Entwicklung- aktuelle Herausforderungen für die ausserschulische Arbeit. In: Umweltbildung im Wald. Arbeitsgemeinschaft Natur-und Umweltbildung, Bundesverband e. V., Hanau. 